\title{
Implementation of Inventory Management in a Footwear Industry
}

\author{
Jeferson Conceição ${ }^{1} \mathbb{D}$, José de Souza ${ }^{2} \mathbb{D}$, Elton Gimenez-Rossini ${ }^{3} \mathbb{D}$, Alfonso Risso ${ }^{4}$, Alexandre Beluco ${ }^{4} \mathbb{D}$ \\ ${ }^{1}$ Faculdades Integradas de Taquara (FACCAT) (Brazil) \\ ${ }^{2}$ Fundação Liberato (Brazil) \\ ${ }^{3}$ Universidade Estadual do Rio Grande do Sul (UERGS) (Brazil) \\ ${ }^{4}$ Universidade Federal do Rio Grande do Sul (UFRGS) (Brazil)
}

conceicao.eng@gmail.com,josesouฉa@liberato.com.br,elton-rossini@uergs.edu.br,alfonso.risso@ufrgs.br,lexf143@gmail.com

Received: May 2020

Accepted: February 2021

\begin{abstract}
:
Purpose: The objective of this research was to implement new inventory management in a footwear company through the analysis of indicators obtained from inventory data collection.

Design/methodology/approach: The ABC analysis methods, demand forecasting, safety stock, reorder point, and economic order quantity were applied. The items in inventory were classified by order of economic importance through $\mathrm{ABC}$ analysis, and the proposed indicators were analyzed to determine the moment the inventory replenishment should be carried out as well as the purchase lot size for each item. The research also investigated the behavior of the demand and pointed out the demand forecasting method that came closest to reality.
\end{abstract}

Findings: The study presents a method of implementing inventory management based on indicators derived from the application of $\mathrm{ABC}$ curve methods, demand forecasting, safety stock, re-fulfillment point, and economic purchased lot. It also indicates how the $\mathrm{ABC}$ classification of stocks can check the most representative materials in stock. The study also highlights that the rejection of modifications can be surpassed by obtaining favorable results.

Research limitations/implications: The inventory management applied in this work is based on indicators that resulted in two primary data that defined the size of the purchased lot to be ordered and the amount of material needed.

Practical implications: The methods of $\mathrm{ABC}$ analysis, demand forecasting, safety stock, reorder point, and economic order quantity were applied. The items in inventory were classified by order of economic importance through $\mathrm{ABC}$ analysis, and the proposed indicators were analyzed to determine the moment the inventory replenishment should be carried out as well as the purchase lot size for each item. The research also explored the behavior of the demand and pointed out the demand forecasting method that came closest to reality.

Originality/value: In this study, a method applied is presented, highlighting the methodological application's importance for inventory management implementation. The study contributes to the encouragement and adoption of methodologies to improve analysis and inventory management in companies.

Keywords: demand forecasting, inventory, $\mathrm{ABC}$ analysis, reorder point 


\section{To cite this article:}

Conceição, J., de Souza, J., Gimenez-Rossini, E., Risso, A., \& Beluco, A. (2021). Implementation of inventory management in a footwear industry. Journal of Industrial Engineering and Management, 14(2), 360-375.

https://doi.org/10.3926/jiem.3223

\section{Introduction}

An adequate industrial arrangement and management tools and techniques are essential to provide agile service to clients. And the inventory exerts a great influence in this matter, given that it is a complex sector, diverse and has high financial value (Santos, Marques, Santos \& Nóbrega, 2017).

Inventory management is a continuous and planned process that aims at organizing goods and materials according to the company's needs, ensuring an adequate supply, balancing supply and demand and avoiding overstock (Singh \& Verma, 2018).

Materials kept in inventory are needed with the primary objective of meeting production orders or deliveries to customers, with the effect of reducing the cost of undelivered or delayed orders and giving quick delivery response (Foreest, Teunter \& Syntetos, 2018).

Inventory management involves some dilemmas, some aspects exert pressure to keep a low inventory, such as cost of capital, storage, charges, insurance and losses, but also aspects that lean toward keeping a high inventory, such as the cost of ordering, of transport, the reduction of unnecessary setups and the better use of labor resources (Krajewski, Ritsman \& Malhotra, 2009). According to Dadouchi and Agard (2018), inventory management is a recurring industrial problem, and there are a few common alternatives to these problems, such as increasing inventory to protect the company against a lack of goods or executing demand forecasting to anticipate the company's needs, maintaining an adequate stock of materials. Also, Krajewski et al. (2009) explain that inventories should be well managed because they mask production problems and, if high, have a negative financial impact.

Rabenschlag and Arreal (2016) argue that a high inventory hides a lot of waste in the production system, making this waste invisible and increasing the production cost; however, they stress that the objective is not to have zero stock, but to make it balanced, with no excess.

Bean, Joubert and Luhandjula (2016) defend that there are difficulties in inventory management in environments where the demand is uncertain. A commonly used technique to forecast the demand is to assume an uncertain parameter and attribute its probability distribution as certain. However, the authors argue that a hybrid model would be the most adequate in this scenario of uncertainties, considering the environment's variables.

Darom, Hishamuddin, H., Ramli and Nopiah (2018) show the consequences of stockout points, in which stock must be increased at a certain risk, varying according to the level of service requirements demanded by the customer. When there is a disruption in the stock supply, production stops, and the lost quantities have to be compensated quickly, hurting sustainability. However, a balance between sustainability and recovery is possible, to attenuate stockout events' chances through a broad study of the relevant parameters.

Applying management tools is essential to optimizing inventory, given that, according to Silva, Menezes, Silva and Nunes (2016), indicators of demand, inventory and delivery time are required for this optimization. These indicators should follow the continuous review model when there is an oscillation of demand, given that the demand is a factor that directly impacts the system. The use of computational resources to feed data, to follow up information and to use it for decision making in inventory management is necessary due to the agility and efficiency it provides, considering the need for immediate action in face of the indicators (Tan \& Karabati, 2013).

To manage inventory it is necessary to know what goods are needed for production, how long the delivery time of suppliers is, how big the physical stock is, how many goods are still to be delivered, what safety stock/margin is needed and when corrective or predictive actions are required (Lukinskiy \& Lukinskiy, 2017). 
It is necessary to emphasize the importance of inventory management to a company. These are funds of high financial value invested and must be well managed to respond to demand quickly and without financial loss, systemically. Since according to Santos, Martins, Alves and Moellmann (2009) requires different actions and philosophies that are aligned with the company's strategy to redirect objectives to have adequate inventory management.

However, many companies still work empirically in inventory, since they do not use technological tools and management methods (Gianesi \& Biazzi, 2011). And even those that use techniques, need to know very well the behavior of their demand to determine the appropriate calculation method for their scenario (Vago, Sousa, Melo, Lara, Fagundes \& Samapio, 2013).

This article presents the results of a research that had the purpose of implementing a stock management by analyzing indicators derived from the inventory data pertinent to the inventory and tools and methods researched that apply to the existing scenario.

\section{Theoretical Framework}

\subsection{Demand Forecasting}

Forecasting is necessary in production management, since many actions need time to take effect; that is, it is necessary to project the future to trigger decisions at the right time (Corrêa \& Corrêa, 2009). To Dias (2008), consumption forecasting is essential to the study of inventories, because it informs which products are necessary, in what amount and when; the author also argues that the basic characteristics of demand forecasting are the starting point of planning, the accuracy of the methods employed and the quality of the hypotheses used.

The increasing number of information updates and the constant demands of customers create oscillations over time, altering the products' life cycle and making it harder and harder to predict consumption (Liuxin, Chen, Keblis $\& \mathrm{Li}, 2018)$. The fluctuation of demand is seen as the great problem in inventory management, since any imprecise forecast may have consequences in several aspects of the supply chain (Dadouchi \& Agard, 2018). Guerreiro, Cruz and Pimentel (2016) show that in some smaller companies there is no specific sector to make market forecasts, so the forecast ends up being carried out by the planning sector, which uses historical demand to project the future; that is, they understand that forecasting is fundamental and the beginning of a production planning.

To Corrêa and Corrêa (2009) there are two types of demand: i) independent demand: it is the future demand for an item that cannot be calculated and needs to be forecast. This type of demand comes with random factors beyond the planner's control; ii) dependent demand: demand originated by some document generated by the planner as a master plan. However, for the plan to be executed, the product's structure needs to have the goods necessary to construct the finished product. According to Moreira (2009), the dependent demand is usually used for raw materials; in this case, the purchase of materials is linked to a production plan. Its demand may fluctuate abruptly. On the other hand, with independent demand, the purchase is not tied to a production plan and has a more constant flow.

To calculate the demand forecast with the concept of simple moving average, we calculate the average of the last three periods (MM3), four periods (MM4) or more (Corrêa \& Corrêa, 2009), as shown in Equation (1):

$$
\text { Moving Average }=\frac{\sum_{n} \text { demand in } n \text { períods }}{n}
$$

$n$ represents the periods.

The calculation of demand forecast by weighted moving average assumes different weights for each period, giving greater importance to the most recent one (Corrêa \& Corrêa, 2009), as shows Equation (2):

$$
\text { Weighted Moving Average }=(0.2 \cdot x)+(0.3 \cdot y)+(0.5 \cdot z)
$$

$x$ represents the third last period

$y$ is the second last

$z$ is the last period. 
The forecast by moving average with exponential smoothing considers the average of the last periods adjusted to the difference of forecast of the last period (Martins \& Laugeni, 2005). See Equation (3):

$$
P_{t}=P_{t-1}+a\left(\mathrm{C}_{t-1}-\mathrm{P}_{t-1}\right)
$$

$P_{t}$ current forecast

$P_{t-1}$ previous forecast

$C_{t-1}$ real consumption in the previous period

a moothing constant (which usually sits between 0,1 and 0,3 ).

According to Moreira (2009), some measures can be used to select the most adequate demand forecasting method, such as Mean Absolute Deviation (MAD) and Mean Squared Error (MSE), as shown in Equations (4), (5) and (6):

$$
\begin{gathered}
\text { Error }=\text { Forecast value }- \text { actual value } \\
M A D=\frac{\sum \mid \text { Error } \mid}{n \text { períods }} \\
M S E=\frac{\sum \text { Error }^{2}}{n \text { períods }-1}
\end{gathered}
$$

According to Wanke (2011), MAD is commonly used to evaluate errors originated from forecasting methods and to

\begin{tabular}{|c|c|c|c|c|c|c|}
\hline \multirow[b]{2}{*}{ Methods } & \multicolumn{6}{|c|}{ Authors } \\
\hline & $\begin{array}{l}\text { Corrêa and } \\
\text { Corrêa (2009) }\end{array}$ & $\begin{array}{l}\text { Martins and } \\
\text { Laugeni (2005) }\end{array}$ & $\begin{array}{l}\text { Tubino } \\
\text { (2009) }\end{array}$ & $\begin{array}{l}\text { Moreira } \\
(2009)\end{array}$ & $\begin{array}{l}\text { Wanke } \\
\text { (2011) }\end{array}$ & Total \\
\hline Simple moving average & $\mathrm{X}$ & $\mathrm{X}$ & $\mathrm{X}$ & $\mathrm{X}$ & $\mathrm{X}$ & 5 \\
\hline Weighted moving average & $\mathrm{X}$ & $\mathrm{X}$ & $\mathrm{X}$ & $\mathrm{X}$ & $\mathrm{X}$ & 5 \\
\hline Moving average with exponential smoothing & $\mathrm{X}$ & $\mathrm{X}$ & $\mathrm{X}$ & $\mathrm{X}$ & - & 4 \\
\hline Linear regression & - & $\mathrm{X}$ & $\mathrm{X}$ & $\mathrm{X}$ & - & 3 \\
\hline Double exponential smoothing & - & $\mathrm{X}$ & $\mathrm{X}$ & - & - & 2 \\
\hline Seasonal smoothing for data with a trend & - & $\mathrm{X}$ & $\mathrm{X}$ & - & - & 2 \\
\hline Seasonal smoothing of linear trends & - & $\mathrm{X}$ & $\mathrm{X}$ & - & - & 2 \\
\hline $\begin{array}{l}\text { Moving average with } 2 \text { nd order exponential } \\
\text { smoothing }\end{array}$ & - & - & - & $\mathrm{X}$ & - & 1 \\
\hline Seasonal smoothing without trend & - & $\mathrm{X}$ & - & - & - & 1 \\
\hline Regression with exponential function & - & - & - & $\mathrm{X}$ & - & 1 \\
\hline Regression with parabolic function & - & - & - & $\mathrm{X}$ & - & 1 \\
\hline Multiple linear regression & - & - & - & $\mathrm{X}$ & - & 1 \\
\hline Trend and cycle smoothing & $\mathrm{X}$ & - & - & - & - & 1 \\
\hline
\end{tabular}
define which one is the most appropriate for the planning of the future demand.

To validate the demand forecasting method, a survey of the procedures addressed by the authors researched in the methodology section of this work occurred. The three most cited methods were selected, as presented in Table 1.

Table 1. Survey of demand forecasting methods 


\subsection{ABC Classification of Inventories}

The $\mathrm{ABC}$ classification is an inventory management auxiliary tool that assumes that few items are responsible for most of the problems of a production system or for most demands that need to be met (Tubino, 2009). According to Geronimo, Mesquita, Ferreira, Pereira and Cutrim (2017), ABC analysis can separate inventory items by financial classification, hence being capable of directing actions toward goods that have greater representativeness and that will, therefore, bring better results, focusing actions on fewer items. To Isoppo, Almeida and Pacheco (2015), a major mistake in management is to apply the same treatment to all inventory items; the items have to be classified according to their relevance and be handled differently, following their characteristics.

\subsection{Safety Stock}

Consumption forecast is fraught with uncertainties because it projects the future based on the past and there may be delays in the suppliers' delivery times. To take these variables into account and attenuate them in the forecasting process, the safety stock system is adopted (Wanke, 2011). According to Corrêa and Corrêa (2009), the safety stock is given by Equation (7):

$$
\text { Eseg }=F S . \sigma \cdot \sqrt{\frac{L T}{P P}}
$$

Eseg safety stock

$S F$ safety factor (function of the level of service intended)

$\sigma$ standard deviation

$L T$ restock time

PP periodicity which the standard deviation refers to.

Martins and Laugeni (2005) define the safety stock equation according to Equation (8), not considering periodicity.

$$
\text { Eseg }=F S \cdot \sigma \cdot \sqrt{L T}
$$

However, Martins and Laugeni (2005) associate the level of service to the material's ABC classification, so that the items in Class A have a lower service level than the ones in Class B, and Class B has a lower level than Class C, as shown in Table 2.

\begin{tabular}{|l|r|r|r|}
\hline \multicolumn{1}{|c|}{ Item class } & \multicolumn{1}{c|}{ A } & \multicolumn{1}{c|}{ B } & \multicolumn{1}{c|}{ C } \\
\hline Minimum service level & $70 \%$ & $80 \%$ & $90 \%$ \\
\hline Minimum Z value & 0.53 & 0.84 & 1.28 \\
\hline Maximum service level & $80 \%$ & $90 \%$ & $95 \%$ \\
\hline Maximum Z value & 0.84 & 1.28 & 1.65 \\
\hline
\end{tabular}

Table 2. Service level (Martins \& Laugeni, 2005)

Corrêa and Corrêa (2009) consider the periodicity concerning the standard deviation, which is prudent considering the oscillation of the material's demand. And Martins and Laugeni (2005) add the table of service level specific to each inventory class.

\subsection{Reorder Point}

The reorder point or point of order defines when the purchase order should be placed, given it is the moment in which the material must be ordered so that it arrives at the right time, considering the variables of restock time and safety stock (Corrêa and Corrêa, 2009). The reorder point system is illustrated in Figure 1, with a constant demand simulation. 


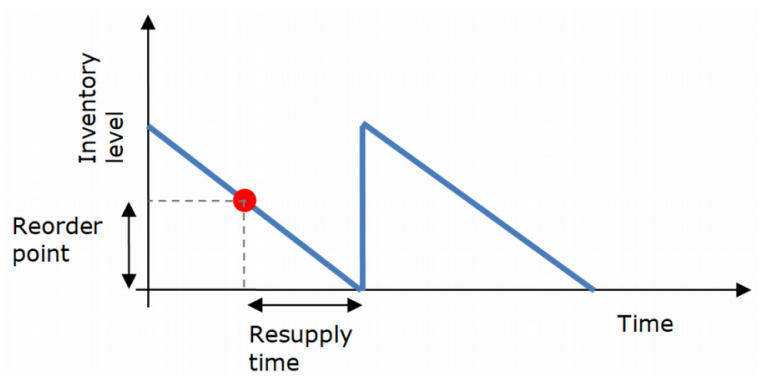

Figure 1. Reorder point (Wanke, 2011)

Martins and Laugeni (2005) define the reorder point calculation to define the ideal moment to generate a purchase, as shown in Equation (9):

$$
R=D .<+E S
$$

$\mathrm{R}$ reorder point

$D$ average demand.

\subsection{Economic Order Quantity}

The economic order quantity has the objective of minimizing total costs by weighing the costs of ordering with the cost of keeping the material in stock, determining the ideal situation (Wanke, 2011). Martins and Laugeni (2005) define the economic order quantity according to Equation (10):

$$
E O Q=\sqrt{\frac{2 \cdot C_{p} \cdot D}{C_{c} \cdot J}}
$$

EOQ economic order quantity

$C_{p}$ cost of placing an order

$D$ demand for the item in the period considered

$C_{c}$ unit cost of the ordered material

$J$ represents the interest rate in the period.

\section{Materials and Methods}

\subsection{Research Application Scenario}

The study was developed in the injection molding sector of a footwear company in Vale do Paranhana, Rio Grande do Sul, with an average production of 8,000 pairs a day and around 1,000 direct employees. The company was founded in 1998, operating in the production of women's shoes. The company has a branch where all the injected items are produced, such as sole, heels, top piece and insole, for which the main materials are: ABS (acrylonitrile butadiene styrene), PVC (polyvinyl chloride), PU (polyurethane), TR (thermoplastic rubber), TPU (thermoplastic polyurethane) and Microgel. The purchases had no technological method. The goods needed to produce injected parts were bought empirically, without any basis on the programmed necessities or the production history, generating high and obsolete inventory. Despite that, there was still the need to pause production due to the lack of a needed good. Currently the inventory of the sector of injection moulding has 130 items provided by a range of 13 suppliers. Of this total, 50 items are obsolete and not used because their life cycle is over, being poor purchasing management.

\subsection{Methodological Procedures}

The methodology used, regarding the procedures, was of case study. The work began with the definition of the research problem, the scenario and the sample. Subsequently, we worked on the stratification of the data, which required creating a database of the company's system, so that the full history of purchases and sale of material is registered and updated in real time. 
The inventory management applied in this work was based on indicators that resulted in two main measures: the definition of the size of the purchase lot to be executed and the amount of material to be ordered. To reach these main indicators, it was necessary to survey other measurable variables, such as: i) demand forecast; ii) ABC classification; iii) safety stock; iv) reorder point; and v) economic order quantity. The chronological sequence of application was based on the studies of Corrêa and Corrêa (2009), Tubino (2009), Moreira (2009), Martins and Laugeni (2005) and Wanke (2011), as shown in Figure 2.

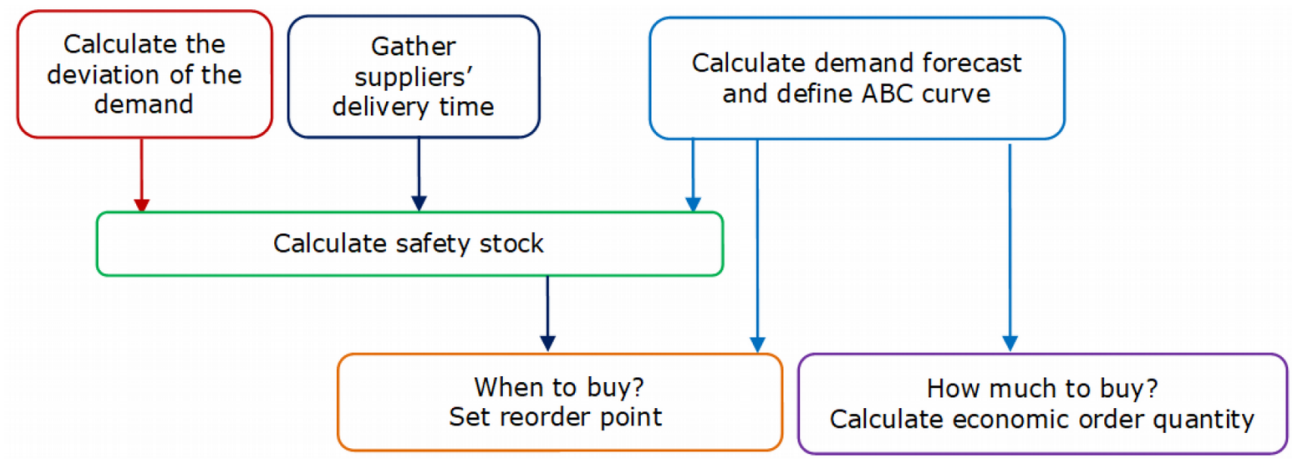

Figure 2. Diagram of the methods applied in the study

The ABC curve was applied to the materials in inventory to identify the most relevant items. With the classification of the items with the $\mathrm{ABC}$ analysis, it was identified that while class A represented only $7 \%$ of the items in inventory, it also represented $71 \%$ of the average monthly consumption value, and that in class $\mathrm{C}$, which had $83 \%$ of the items in inventory, represented only $10 \%$ of the consumption value, as shown in Figure 3.

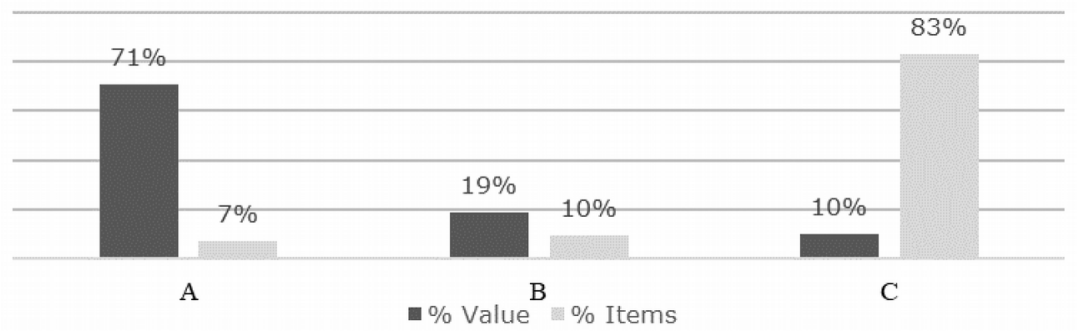

Figure 3. Inventory categorization

$\mathrm{ABC}$ analysis shows that few items represent the largest financial value and define the higher importance of class $\mathrm{A}$ in inventory adjustment and control. It clarifies that the optimized actions and inventory of these items will represent a lower financial investment employed in inventory management. Figure 4 shows the ABC curve with the representativeness of the items in inventory and their classes.

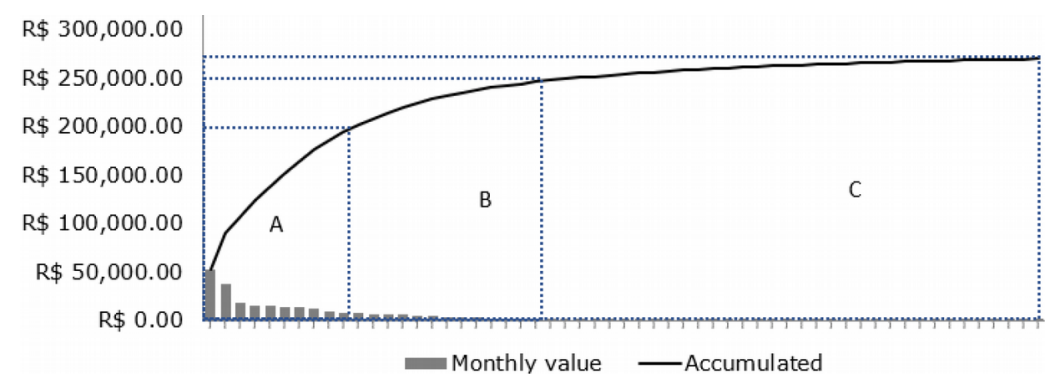

Figure 4. ABC curve 
In the following stage, the demand for class A items in 2017 was analyzed. The year 2017 is not part of the period studied in this work; however, the company had the data, so we used it as an initial step to analyze the demand, to calculate the standard deviation of demand and evaluate the possible incidence of seasonal or cyclical demand, as shown in Figure 5.

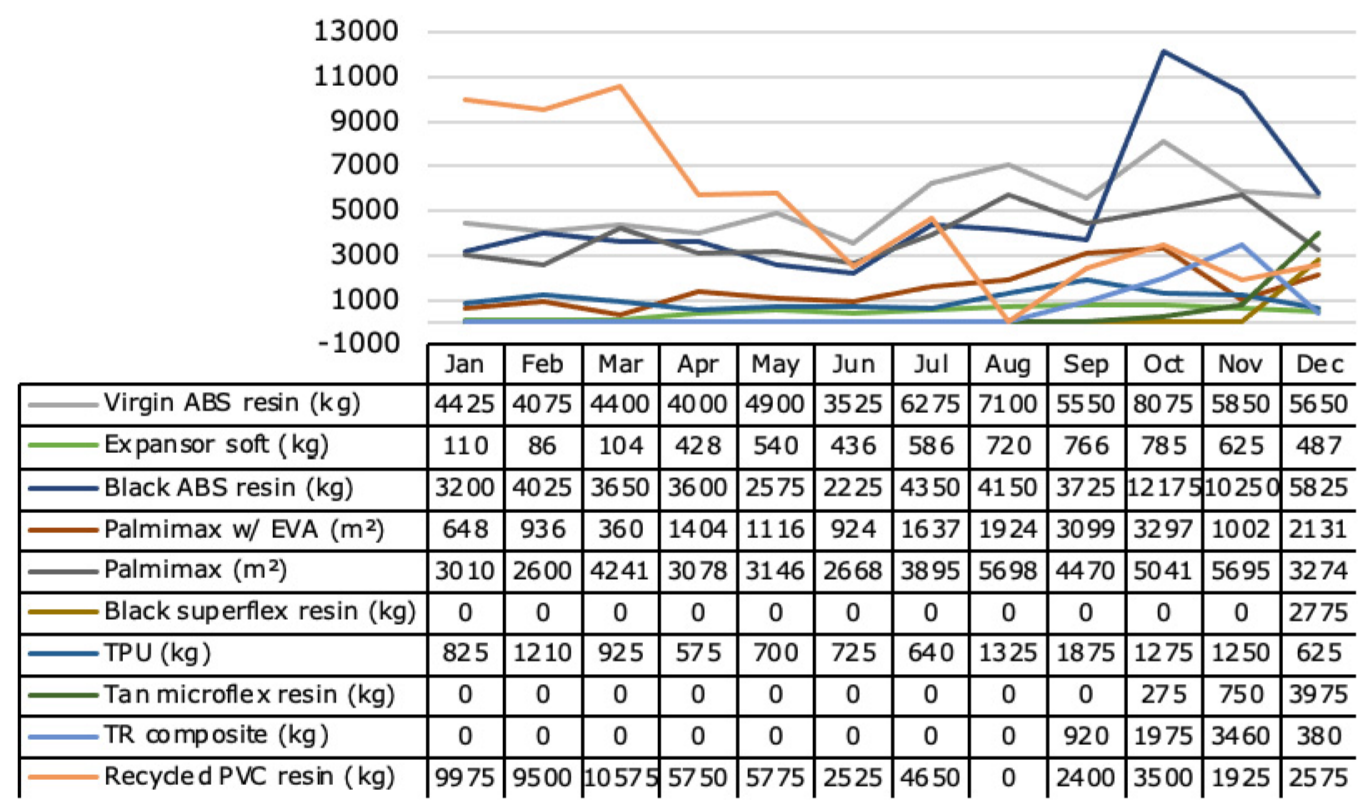

Figure 5. Demand for class A items

Although some materials had sharper oscillations in the period, we used the concept of independent demand and the calculation of moving average of three periods, which is the average of the real demand of the last three periods projected to forecast the future demand. The moving average method was selected because of its simplicity; however, along the work other methods will be simulated to identify the most appropriate for the scenario studied. The calculation of demand forecast was executed for all the goods in inventory. Table 3 shows the data on the demand forecast for class A items based on the data collected in the last month of research, May 2018, therefore forecasting the demand for June 2018.

\begin{tabular}{|c|c|c|c|c|c|}
\hline Material & U.M. & $\begin{array}{l}\text { Real demand } \\
\text { (March) }\end{array}$ & $\begin{array}{l}\text { Real demand } \\
\text { (April) }\end{array}$ & $\begin{array}{l}\text { Real demand } \\
\text { (May) }\end{array}$ & $\begin{array}{l}\text { Demand forecast } \\
\text { for June (MM3) }\end{array}$ \\
\hline Virgin ABS resin & $\mathrm{kg}$ & 8450 & 4000 & 4750 & 5733 \\
\hline Expansor soft & $\mathrm{kg}$ & 464 & 290 & 377 & 377 \\
\hline Black ABS resin & $\mathrm{kg}$ & 4450 & 3900 & 4350 & 4233 \\
\hline Palmimax w/ EVA & $\mathrm{m}^{2}$ & 1105 & 2518 & 574 & 1399 \\
\hline Palmimax & $\mathrm{m}^{2}$ & 3650 & 2200 & 2300 & 2717 \\
\hline Black superflex resin & $\mathrm{kg}$ & 5641 & 3275 & 2216 & 3711 \\
\hline TPU & $\mathrm{kg}$ & 1050 & 800 & 925 & 925 \\
\hline Tan microflex resin & $\mathrm{kg}$ & 3100 & 2350 & 3624 & 3025 \\
\hline TR composite & $\mathrm{kg}$ & 1260 & 665 & 1005 & 977 \\
\hline Recycled PVC resin & $\mathrm{kg}$ & 2800 & 1850 & 0 & 1550 \\
\hline
\end{tabular}

Table 3. Demand forecast 
The application of the calculation used to obtain the data presented in Table 2 is shown in Equation (11).

$$
M M 3=\frac{(8450+4000+4750)}{3}=5733 \mathrm{~kg}
$$

Subsequently, we gathered data about the suppliers available for each material in inventory, their time of delivery and their minimum order quantity. Table 4 shows the data for class A.

\begin{tabular}{|l|r|r|r|}
\hline \multicolumn{1}{|c|}{ Material } & $\begin{array}{c}\text { Time of delivery } \\
\text { (Days) }\end{array}$ & $\begin{array}{c}\text { Time of delivery } \\
\text { (Months) }\end{array}$ & $\begin{array}{c}\text { Minimum } \\
\text { lot }\end{array}$ \\
\hline Virgin ABS resin & 10 & 0.45 & $25 \mathrm{~kg}$ \\
\hline Expansor soft & 15 & 0.68 & $150 \mathrm{~kg}$ \\
\hline Black ABS resin & 10 & 0.45 & $25 \mathrm{~kg}$ \\
\hline Palmimax w/ EVA & 15 & 0.68 & $50 \mathrm{~m}^{2}$ \\
\hline Palmimax & 15 & 0.68 & $50 \mathrm{~m}^{2}$ \\
\hline Black superflex resin & 10 & 0.45 & $25 \mathrm{~kg}$ \\
\hline TPU & 5 & 0.23 & $25 \mathrm{~kg}$ \\
\hline Tan microflex resin & 10 & 0.45 & $25 \mathrm{~kg}$ \\
\hline TR composite & 10 & 0.45 & $20 \mathrm{~kg}$ \\
\hline Recycled PVC resin - black & 10 & 0.45 & $25 \mathrm{~kg}$ \\
\hline
\end{tabular}

Table 4. Time of delivery and minimum order quantity

To calculate the safety stock, we used the Equation (7), Eseg $=F S . \sigma \cdot \sqrt{\frac{L T}{P P}}$, because it considers the periodicity of the standard deviation and, given that the standard deviation was obtained from twelve months, it reduces the uncertainty due to the longer period of analysis. However, a service level of $80 \%$ was used for class A, $90 \%$ for class $\mathrm{B}$ and $95 \%$ for class $\mathrm{C}$, to execute different actions for each $\mathrm{ABC}$ curve class. Table 5 shows the safety stocks of the class A items.

\begin{tabular}{|c|c|c|c|c|c|c|c|}
\hline Material & U.M. & $\begin{array}{l}\text { Monthly cons. } \\
\text { (U.M.) }\end{array}$ & $\begin{array}{l}\text { Service } \\
\text { level }\end{array}$ & $\begin{array}{l}\text { Service } \\
\text { factor } \\
\text { (FS) }\end{array}$ & $\begin{array}{l}\text { Standard } \\
\text { deviation } \\
\text { (U.M.) ( } \sigma)\end{array}$ & $\begin{array}{l}\text { Restock time } \\
\text { (months) } \\
\text { (LT) }\end{array}$ & $\begin{array}{l}\text { Safety } \\
\text { stock } \\
\text { (U.M.) }\end{array}$ \\
\hline Virgin ABS resin & $\mathrm{kg}$ & 5733 & $80 \%$ & 0.84 & 1364 & 0.45 & 223 \\
\hline Expansor soft & $\mathrm{kg}$ & 377 & $80 \%$ & 0.84 & 253 & 0.68 & 51 \\
\hline Black ABS resin & $\mathrm{kg}$ & 4233 & $80 \%$ & 0.84 & 3075 & 0.45 & 503 \\
\hline Palmimax w/ EVA & $\mathrm{m}^{2}$ & 1399 & $80 \%$ & 0.84 & 927 & 0.68 & 186 \\
\hline Palmimax & $\mathrm{m}^{2}$ & 2717 & $80 \%$ & 0.84 & 1122 & 0.68 & 225 \\
\hline Black superflex resin & $\mathrm{kg}$ & 3711 & $80 \%$ & 0.84 & 801 & 0.45 & 131 \\
\hline TPU & $\mathrm{kg}$ & 925 & $80 \%$ & 0.84 & 394 & 0.23 & 46 \\
\hline Tan microflex resin & $\mathrm{kg}$ & 3025 & $80 \%$ & 0.84 & 1142 & 0.45 & 187 \\
\hline TR composite & $\mathrm{kg}$ & 977 & $80 \%$ & 0.84 & 1091 & 0.45 & 178 \\
\hline Black PVC resin & $\mathrm{kg}$ & 1550 & $80 \%$ & 0.84 & 3474 & 0.45 & 568 \\
\hline
\end{tabular}

Table 5. Safety stock 
Equation 12 presents the application of the calculation used to obtain the data shown in Table 5.

$$
\text { Eseg }=0.84 .1364 \cdot \sqrt{\frac{0.45}{12}}=223 \mathrm{~kg}
$$

However, the service levels used must be adequate for each scenario, with a systemic evaluation of the company as a whole, since it is a value that directly impacts the possibility of there being production stoppages due to lack of inventory items, therefore also being a factor for overstocking. It is, thus, an extremely important decision that may not apply to other scenarios with different inventory variables.

With the data on demand forecast, suppliers' time of delivery and safety stock, it was possible to define the reorder point, which is the indicator that shows the exact moment to execute a purchase order. The reorder point must calculate the product in demand with the restock time, added to the safety stock, as shown in Equation 9, $R=D .<+E S$. However, it is important to emphasize that the reorder point needs to consider the physical inventory plus the amount of goods bought and not delivered. A second purchase order can be placed before the first one is delivered. Table 6 shows the reorder point for class A items.

\begin{tabular}{|c|c|c|c|c|c|}
\hline Material & U.M. & $\begin{array}{l}\text { Monthly consumption } \\
\text { (U.M.) } \\
\text { (D) }\end{array}$ & $\begin{array}{l}\text { Time of delivery } \\
\text { (months) } \\
\text { (LT) }\end{array}$ & $\begin{array}{l}\text { Safety stock } \\
\text { (U.M.) } \\
\text { (ES) }\end{array}$ & $\begin{array}{l}\text { Reorder point } \\
\text { (U.M.) } \\
\text { (R) }\end{array}$ \\
\hline Virgin ABS resin & $\mathrm{kg}$ & 5733 & 0.45 & 223 & 2803 \\
\hline Expansor soft & $\mathrm{kg}$ & 377 & 0.68 & 51 & 307 \\
\hline Black ABS resin & $\mathrm{kg}$ & 4233 & 0.45 & 503 & 2408 \\
\hline Palmimax w/ EVA & $\mathrm{m}^{2}$ & 1399 & 0.68 & 186 & 1137 \\
\hline Palmimax & $\mathrm{m}^{2}$ & 2717 & 0.68 & 225 & 2073 \\
\hline Black superflex resin & $\mathrm{kg}$ & 3711 & 0.45 & 131 & 1801 \\
\hline TPU & $\mathrm{kg}$ & 925 & 0.23 & 46 & 259 \\
\hline Tan microflex resin & $\mathrm{kg}$ & 3025 & 0.45 & 187 & 1548 \\
\hline TR composite & $\mathrm{kg}$ & 977 & 0.45 & 178 & 618 \\
\hline Recycled PVC resin - black & $\mathrm{kg}$ & 1550 & 0.45 & 568 & 1266 \\
\hline
\end{tabular}

Table 6. Reorder point

Equation 13 shows the application of the calculation used to obtain the data presented in Table 6.

$$
P R=(5733.0 .45)+223=2803 \mathrm{~kg}
$$

After defining the moment to order a purchased lot, we delimited the size of the purchased lot according to the concept of economic order quantity used in Equation $10 \mathrm{EOQ}=\sqrt{\frac{2 \cdot C_{p} \cdot D}{C_{c} \cdot J}}$ used to build Table 5. For the definition of the purchase lot, we weighted the ordering costs and the costs of maintaining inventory. That calculation was executed for each item and rounded up to suit the minimum lot size required by suppliers. The ordering cost was originated from the cost of one work hour, which is the average time needed to place a purchase order and receive the material. The interest rate applied used the value $0.06 \%$, which is the average yield of savings accounts. Table 7 has the data regarding the purchase lot size of class $\mathrm{A}$ items. 


\begin{tabular}{|c|c|c|c|c|c|c|c|c|}
\hline Material & U.M. & $\begin{array}{l}\text { Monthly } \\
\text { consumption } \\
\text { (U.M.) } \\
\text { (D) }\end{array}$ & $\begin{array}{l}\text { Ordering } \\
\text { cost } \\
\text { (Cp) }\end{array}$ & $\begin{array}{l}\text { Unit cost } \\
\text { (Cc) }\end{array}$ & $\begin{array}{l}\text { Interest } \\
\text { rate } \\
\text { applied }\end{array}$ & $\begin{array}{l}\text { Minimum } \\
\text { purchase } \\
\text { lot } \\
\text { (U.M.) }\end{array}$ & $\begin{array}{c}\text { EOQ } \\
\text { (U.M.) }\end{array}$ & $\begin{array}{l}\text { Amount } \\
\text { needed } \\
\text { (U.M.) }\end{array}$ \\
\hline Virgin ABS resin & $\mathrm{kg}$ & 5733 & $\mathrm{R} \$ 10.00$ & $\mathrm{R} \$ 9.10$ & $0.6 \%$ & 25 & 1449 & 1450 \\
\hline Expansor soft & $\mathrm{kg}$ & 377 & $\mathrm{R} \$ 10.00$ & $\mathrm{R} \$ 101.63$ & $0.6 \%$ & 150 & 111 & 150 \\
\hline Black ABS resin & $\mathrm{kg}$ & 4233 & $\mathrm{R} \$ 10.00$ & $\mathrm{R} \$ 4.12$ & $0.6 \%$ & 25 & 1850 & 1850 \\
\hline Palmimax w/ EVA & $\mathrm{m}^{2}$ & 1399 & $\mathrm{R} \$ 10.00$ & $\mathrm{R} \$ 11.18$ & $0.6 \%$ & 50 & 646 & 650 \\
\hline Palmimax & $\mathrm{m}^{2}$ & 2717 & $\mathrm{R} \$ 10.00$ & $\mathrm{R} \$ 5.43$ & $0.6 \%$ & 50 & 1292 & 1300 \\
\hline Black superflex resin & $\mathrm{kg}$ & 3711 & $\mathrm{R} \$ 10.00$ & $\mathrm{R} \$ 3.61$ & $0.6 \%$ & 25 & 1851 & 1850 \\
\hline TPU & $\mathrm{kg}$ & 925 & $\mathrm{R} \$ 10.00$ & $\mathrm{R} \$ 14.17$ & $0.6 \%$ & 25 & 466 & 475 \\
\hline Tan microflex resin & $\mathrm{kg}$ & 3025 & $\mathrm{R} \$ 10.00$ & $\mathrm{R} \$ 3.89$ & $0.6 \%$ & 25 & 1610 & 1600 \\
\hline
\end{tabular}

Table 7. Purchase lot size

Equation 14 has the application of the calculation used to obtain the data shown in Table 7.

$$
\text { EOQ }=\sqrt{\frac{2.10 \cdot 5733}{9.1 \cdot 0.006}}=1449 \mathrm{~kg}
$$

With the definition of all indicators, we created a table crossing the calculations, which was inserted into an electronic spreadsheet. The updated data about the demand are imported directly from the system that registers the entries and exits of goods. In addition to the indicators, the amount of material pending delivery was added to be considered at the reorder point, as shown in Table 8.

\begin{tabular}{|l|r|r|r|r|r|r|r|r|r|r|r|}
\hline & U.M. & $\begin{array}{c}\text { Monthly } \\
\text { consumption } \\
\text { (U.M.) }\end{array}$ & $\begin{array}{c}\text { Inventory } \\
\text { (U.M) }\end{array}$ & $\begin{array}{c}\text { Stock to be } \\
\text { delivered } \\
\text { (U.M.) }\end{array}$ & $\begin{array}{r}\text { Time of } \\
\text { delivery } \\
\text { (Month) }\end{array}$ & $\begin{array}{c}\text { Safety } \\
\text { stock } \\
\text { (U.M.) }\end{array}$ & $\begin{array}{c}\text { Reorder } \\
\text { point } \\
\text { (U.M.) }\end{array}$ & $\begin{array}{c}\text { Days } \\
\text { before } \\
\text { purchase }\end{array}$ & $\begin{array}{c}\text { Amount } \\
\text { needed } \\
\text { (U.M.) }\end{array}$ & $\begin{array}{c}\text { Minimum } \\
\text { purchase } \\
\text { lot (U.M.) }\end{array}$ & $\begin{array}{c}\text { EOQ } \\
\text { (U.M.) }\end{array}$ \\
\hline Virgin ABS resin & $\mathrm{kg}$ & 5733 & 1225 & 3000 & 0.45 & 223 & 2803 & 5 & 1450 & 25 & 1449 \\
\hline Expansor soft & $\mathrm{kg}$ & 377 & 347 & 450 & 0.68 & 51 & 307 & 29 & 150 & 150 & 111 \\
\hline Black ABS resin & $\mathrm{kg}$ & 4233 & 1300 & 3000 & 0.45 & 503 & 2408 & 10 & 1850 & 25 & 1850 \\
\hline $\begin{array}{l}\text { Palmimax w/ } \\
\text { EVA }\end{array}$ & $\mathrm{m}^{2}$ & 1399 & 7970 & 0 & 0.68 & 186 & 1137 & 107 & 650 & 50 & 646 \\
\hline Palmimax & $\mathrm{m}^{2}$ & 2717 & 5300 & 0 & 0.68 & 225 & 2073 & 26 & 1300 & 50 & 1292 \\
\hline $\begin{array}{l}\text { Black superflex } \\
\text { resin }\end{array}$ & $\mathrm{kg}$ & 3711 & 2475 & 4000 & 0.45 & 131 & 1801 & 28 & 1850 & 25 & 1851 \\
\hline TPU & $\mathrm{kg}$ & 925 & 575 & 0 & 0.23 & 46 & 259 & 8 & 475 & 25 & 466 \\
\hline $\begin{array}{l}\text { Tan microflex } \\
\text { resin }\end{array}$ & $\mathrm{kg}$ & 3025 & 225 & 3000 & 0.45 & 187 & 1548 & 12 & 1600 & 25 & 1610 \\
\hline TR composite & $\mathrm{kg}$ & 977 & 840 & 0 & 0.45 & 178 & 618 & 5 & 580 & 20 & 582 \\
\hline $\begin{array}{l}\text { Recycled PVC } \\
\text { resin - black }\end{array}$ & $\mathrm{kg}$ & 1550 & 2500 & 0 & 0.45 & 568 & 1266 & 18 & 1000 & 25 & 990 \\
\hline
\end{tabular}

Table 8. Indicators

The reorder point was transformed into days left before purchase, to facilitate its comprehension and schedule the next purchase. This indicator results from the difference between the reorder point and the sum of the physical stock with the stock being transported, divided by the average daily consumption, as shows Equation (15): 


$$
D F C=\frac{(E F+E T)-P R}{C D}
$$

$D F C$ days left before purchas

$P R$ reorder point

$E F$ amount of physical stock

ET stock being transported (bought and not yet delivered)

$C D$ average daily consumption.

The missing day's indicator is essential to identify if you are close to making a new purchase. This highlights the critical items that must be purchased with priority to respect the delivery time of the material so that it is available at the exact moment of need.

The column that indicates the days left before placing a new purchase order was formatted according to the logic of traffic lights: the color red meaning that the purchase date is close, and green meaning that it is still far away. The objective is to signal clearly which materials need to be bought shortly.

The table created in the electronic spreadsheet has automated data feed to expose the indicators for a more efficient inventory management. Still, it does not affect any change in the system, being simply a signaling tool. As a result of this automated feed, the system is continuously being reviewed. Any changes in the scenario, such as an increase in consumption or delivery delay, will be shown in the indicators, which are updated in real time to take on time. The period of data collection was also used to evaluate a more adequate method for demand forecasting. Although the calculation of the moving average of three periods was used, it was also calculated in other methods studied, in class A, to evaluate the most appropriate method for the studied demand.

\section{Results Analysis}

After applying the proposed methodology and using the table of indicators as determinants for inventory maintenance actions, the alterations and results found in comparing the previous scenario with the progression of the scenario existent after the application were assessed. Figure 6 presents a reduction of $48 \%$ in the total inventory value when comparing December 2017 with May 2018, representing a reduction of R\$386,614.74. Figure 6 also shows the demand per period, proving that the inventory reduction is not an effect of a demand reduction.

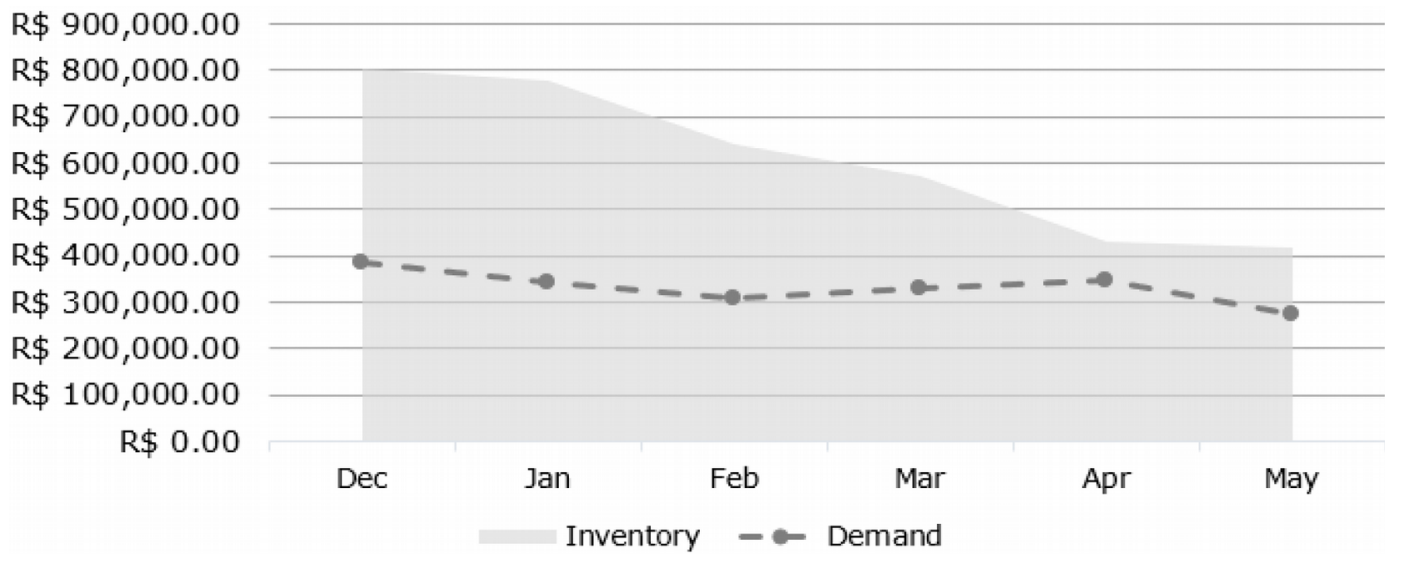

Figure 6. Total inventory value and demand

The reduction in inventory value was distributed by class, as shown in Figure 7 . We can see that $85 \%$ of the reduction happened with class A materials, $20 \%$ with class B, and class C increased the inventory value in $6 \%$. Hence, with the application of $\mathrm{ABC}$ analysis, it was possible to have a better fitted inventory for the most financially representative class and a higher inventory for class $\mathrm{C}$, which is less representative financially, according to Tubino (2009). 


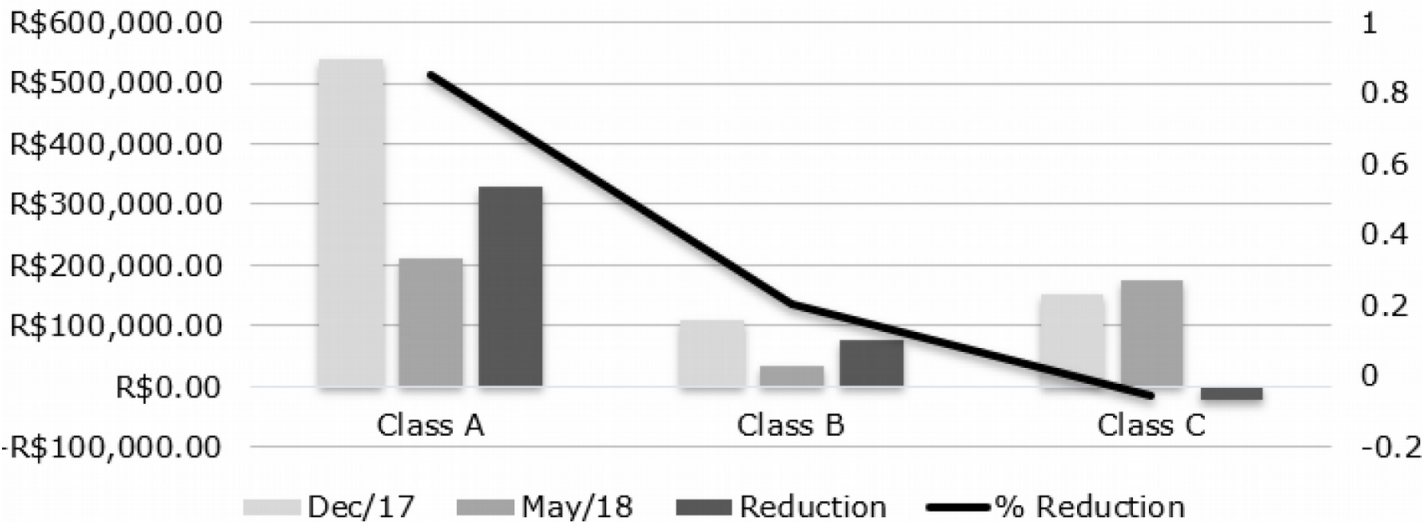

Figure 7. Inventory reduction by class

In class $\mathrm{A}$, there was the most significant reduction in stock compared to the previous scenario and after the application of the methodology. The deduction results in a difference of $\mathrm{R} \$ 330,219.02$ since it is in class $\mathrm{A}$ that the most financially representative items are.

The results achieved in class A were further detailed by material, to identify the individual behavior of each item. As shown in Figure 8, the material "palmimax" had the largest reduction: R $\$ 92,444.60$, representing $24 \%$ of the total reduction. With the reduction of the values spent on this material, we can see how important the use of indicators is in the analysis and inventory decision-making. Given that the initial inventory occupied $12.469 \mathrm{~m}^{2}$, while the average monthly consumption is $3.912 \mathrm{~m}^{2}$ and the supplier's time of delivery is of only 3 weeks, consolidating the application point method exposed by Martins and Laugeni (2005). But exposing the exaggeration of stock and safety margins and the lack of knowledge of the demand in the previous scenario.

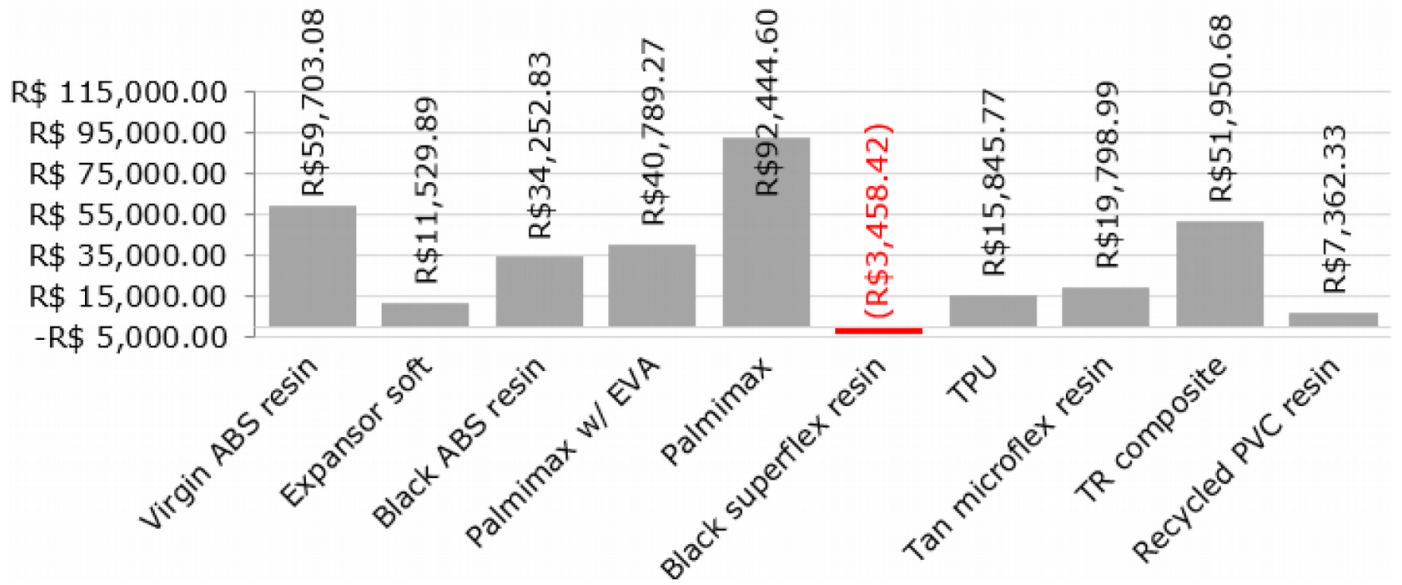

Figure 8. Class A inventory reduction

The Figure 8 also shows that the reduction of the materials' inventory value was not proportional for every item; similarly, the previous inventory was not excessive for every item, and the black superflex resin even presented an increase in its inventory number in the second scenario, with an addition of $\mathrm{R} \$ 3,458.42$

After selecting the methods of demand forecasting, we executed the simulations and compared the forecasted and actual numbers of the demand. That made it possible for us to assess that the weighted average came closer to the demand's actual behavior, varying $25 \%$ compared to it. In comparison, the moving and exponential averages varied $34 \%$ and $46 \%$, respectively, as shown in Table 9. 


\begin{tabular}{|c|c|c|c|c|c|c|c|c|}
\hline \multirow[b]{2}{*}{ Material } & \multirow[b]{2}{*}{ U.M. } & \multirow{2}{*}{$\begin{array}{c}\text { Method }> \\
\text { Real } \\
\text { demand }\end{array}$} & \multicolumn{2}{|c|}{$\begin{array}{c}\text { Moving average } \\
\text { (Eq. 1) }\end{array}$} & \multicolumn{2}{|c|}{$\begin{array}{l}\text { Weighted } \\
\text { (Eq. 2) }\end{array}$} & \multicolumn{2}{|c|}{$\begin{array}{l}\text { Exponential } \\
\text { (Eq. 3) }\end{array}$} \\
\hline & & & $\begin{array}{l}\text { MAD } \\
\text { (Eq. 5) }\end{array}$ & $\begin{array}{l}\text { In relation } \\
\text { to demand } \\
\qquad(\%)\end{array}$ & $\begin{array}{l}\mathrm{MAD} \\
\text { (Eq. 5) }\end{array}$ & $\begin{array}{l}\text { In relation } \\
\text { to demand } \\
\qquad(\%)\end{array}$ & $\begin{array}{l}\mathrm{MAD} \\
(\mathrm{Eq} \cdot 5)\end{array}$ & $\begin{array}{l}\text { In relation } \\
\text { to demand } \\
\qquad(\%)\end{array}$ \\
\hline Virgin ABS resin & $\mathrm{kg}$ & 6133 & 1401 & 23 & 976 & 16 & 1806 & 29 \\
\hline Expansor soft & $\mathrm{kg}$ & 439 & 95 & 22 & 68 & 16 & 142 & 32 \\
\hline Black ABS resin & $\mathrm{kg}$ & 6506 & 1668 & 26 & 1193 & 18 & 2667 & 41 \\
\hline Palmimax w/ EVA & $\mathrm{m}^{2}$ & 1220 & 734 & 60 & 567 & 46 & 1014 & 83 \\
\hline Palmimax & $\mathrm{m}^{2}$ & 3912 & 747 & 19 & 547 & 14 & 1133 & 29 \\
\hline Black superflex resin & $\mathrm{kg}$ & 3084 & 1606 & 52 & 1123 & 36 & 2368 & 77 \\
\hline TPU & $\mathrm{kg}$ & 1061 & 246 & 23 & 178 & 17 & 263 & 25 \\
\hline Tan microflex resin & $\mathrm{kg}$ & 2789 & 868 & 31 & 621 & 22 & 1090 & 39 \\
\hline TR composite & $\mathrm{kg}$ & 1376 & 644 & 47 & 471 & 34 & 699 & 51 \\
\hline \multirow[t]{2}{*}{ Recycled PVC resin - black } & $\mathrm{kg}$ & 1728 & 622 & 36 & 470 & 27 & 959 & 55 \\
\hline & & & $A v,->$ & 34 & & 25 & & 46 \\
\hline
\end{tabular}

Table 9. Comparison of the methods of demand forecasting

It is important to point out that the method used to reach these results was specific to this scenario's conditions, with its variables of service level, demand oscillation and range of items. Furthermore, this same scenario may present demand oscillations that require a revision of the method. Hence, an ongoing assessment of the method is necessary. The higher the standard deviation is compared to the average, the greater the possibility of there being stockout events, given that the uncertainty regarding the demand is greater, which may lead to production stops.

Although the characteristics of price and quality of inputs have significant importance in the purchasing process, according to Endo, Cerqueira, Silva, Nery \& Kawamoto-Junior (2017), this work did not consider these aspects because they are consolidated items already defined.

The results were satisfactory if we compare to the previous scenario that there was neither a standardized procedure nor inventory management information. However, it is still far from a system aligned with what is most current in supply chain management 4.0, which according to Frazzon, Rodriguez, Pereira, Pires end Uhlmann (2019) is the use of technology capable of exchanging information in real time with suppliers. This system can react to the movements and take action of its own, evolving processes in an automated way with full integration.

\section{Conclusion}

This paper presents the results of an applied research that had the objective of implementing an indicators-based inventory management in the sector of injection moulding of a footwear company. The indicators were generated from applying the methods of $\mathrm{ABC}$ analysis, demand forecasting, safety stock, reorder point and economic order quantity. The inventory items were classified according to their financial relevance, and the indicators were used to determine the right moment to restock and the right amount for each item.

The analysis revealed that the amount of some materials kept in inventory was not compatible with their demand. The demand was not being projected, generating the excess of some items and shortage of others.

With the ABC analysis of the inventory, we were able to single out the most relevant materials and prioritize their monitoring and use. The demand forecast was generated with basis on the sector's consumption history, and with that it was possible to calculate the safety stock, the reorder point and the economic order quantity.

During the development and conclusion of the research, it became apparent how important and necessary it is to use applied methods, for they made it possible to analyze and manage inventory based on the indicators, and, as a result, there was a reduction of $48 \%$ in the value of inventory, representing a reduction of $\mathrm{R} \$ 386,614.74$. 
During the study's application, there was a natural rejection of the team due to the changes in the work routine, and many times there was fear of purchasing items under the uncertainty of there being a stockout. However, as the results started showing without stockout incidences, the team understood the importance and strength of the proposed method.

For future works, we suggest improving the indicators, given that there are still gaps for some materials that could have their inventory values reduced. Another matter to be considered is the study of suppliers and the reduction of their delivery time, given that this work simply used the delivery times of existing suppliers, with no suggestions on how to reduce this wait nor to look for new suppliers.

A study of the obsolete items in inventory can also be executed in a future work, as they accounted for 38.5\% of the inventory items. A new purpose for these items can further improve the results.

\section{Declaration of Conflicting Interests}

The authors declared no potential conflicts of interest with respect to the research, authorship, and/or publication of this article.

\section{Funding}

The authors received no financial support for the research, authorship, and/or publication of this article.

\section{References}

Bean, W.L., Joubert, J.W., \& Luhandjula, M.K. (2016). Inventory management under uncertainty: A military application. Computers \& Industrial Engineering, 96, 96-107. https://doi.org/10.1016/j.cie.2016.03.016

Corrêa, H.L., \& Corrêa, C.A. (2009). Administração de produção e operações: manufatura e serviços: uma abordagem estratégica (2nd ed.). São Paulo: Atlas.

Dadouchi, C., \& Agard, B. (2018). Lowering penalties related to stock-outs by shifting demand in product recommendation systems. Decision Support Systems, 114, 61-69. https://doi.org/10.1016/j.dss.2018.08.004

Darom, N.A., Hishamuddin, H., Ramli, R., \& Nopiah, Z.M. (2018). An inventory model of supply chain disruption recovery with safety stock and carbon emission consideration. Journal of Cleaner Production, 197(1), 1011-1021. https://doi.org/10.1016/j.jclepro.2018.06.246

Dias, M.A.P. (2008). Administração de Materiais: uma abordagem logística (4th ed.). São Paulo: Atlas.

Endo, L.M.A., Cerqueira, M.C., Silva, G.N., Nery, L.A.S.S., \& Kawamoto-Junior, L. (2017). Descriptive and comparative study of the purchasing activity: a case study in a food company. Brazilian Journal of Operations \& Production Management, 14(1), 265-271. https://doi.org/10.14488/BJOPM.2017.v14.n2.a14

Foreest, N.D. Van., Teunter, R.H., \& Syntetos, A.A. (2018). Base-stock policies with reservations. Omega, 81, 48-56 https://doi.org/10.1016/j.omega.2017.09.008

Frazzon, E.M., Rodriguez, C.M.T., Pereira, M.M., Pires, M.C., \& Uhlmann, I. (2019). Towards Supply Chain Management 4.0. Brazilian Journal of Operations \& Production Management, 16(2), 180-191. https://doi.org/10.14488/BJOPM.2019.v16.n2.a2

Geronimo, M.S., Mesquita, A.L.G., Ferreira, E.M., Pereira, A.C.S., \& Cutrim, R.M. (2017). A utilização do lote econômico de compra para aquisição de itens de maior representatividade: um estudo em estoque farmacêutico. Anais: XXXVII ENEGEP - Encontro Nacional de Engenharia de Producão. Joinville, SC: Abepro.

Gianesi, I.G.N., \& Biazzi, J.L. (2011). Gestão estratégica de estoques. R. Adm., São Paulo, 6(3), 290-304. https://doi.org/10.5700/rausp1013

Guerreiro, R.P., Cruz, R.G.G., \& Pimentel, F.Q.A. (2016). Aplicação de técnicas de previsão de demanda em uma loja de materiais de construção. Anais: XXXVI ENEGEP - Encontro Nacional de Engenharia de Produção. João Pessoa, PB: Abepro. 
Isoppo, A.S., Almeida, S.R., \& Pacheco, D.A.J. (2015). Análise da gestão de estoques em uma indústria de equipamentos de limpeza. Revista Espacios, 36, 6.

Krajewski, L., Ritsman, L., \& Malhotra, M. (2009). Administração de Produção e Operaçoes. São Paulo: Pearson Prentice Hall.

Liuxin, C., Chen, X., Keblis, M.F., \& Li, G. (2018). Optimal pricing and replenishment policy for deteriorating inventory under stock-level-dependent, time-varying and price-dependent demand. Computers \& Industrial Engineering. https://doi.org/10.1016/j.cie.2018.06.005

Lukinskiy, V., \& Lukinskiy, V. (2017). Evaluation of Stock Management Strategies Reliability at Dependent Demand. Procedia Engineering, 178, 53-56. https://doi.org/10.1016/i.proeng.2017.01.060

Martins, P.G., \& Laugeni, F.P. (2005). Administração da Produção (2nd ed.). São Paulo: Saraiva.

Moreira, D.A. (2009). Administração da produção e operações (2nd ed.). São Paulo: Cengage Learning.

Rabenschlag, D.R., \& Arreal, G. (2016). Aplicação do modelo de lote econômico de compra em uma empresa de máquinas para cassinos de Guadalajara México. Anais: XXXVI ENEGEP - Encontro Nacional de Engenharia de Produção. João Pessoa, PB: Abepro.

Santos, D.M.P., Marques, R.R.R., Santos, J.M., \& Nóbrega, M.R.A. (2017). Gestão de estoque: um estudo de caso na eletro laser no município de Patos - PB. Anais: XXIV SIMPEP - Simpósio de Engenharia de Produção. Bauru, SP.

Santos, R.F., Martins, F.A.S., Alves, J.M., \& Moellmann, A.H. (2009). A Real Application of the Theory of Constraints to Supply Chain Management in Brazil. Brazilian Journal of Operations \& Production Management, 7,(2), 81-100. Available at: https://bjopm.emnuvens.com.br/bjopm/article/view/V7N2A5

Silva, D.R., Menezes, F.M., Silva, M.F., \& Nunes, F.L. (2016). Avaliação dos impactos da aplicação de gestão de estoques em uma indústria metal mecânica: um estudo de caso no Brasil. Revista Espacios, 37, 2.

Singh, D., \& Verma, A. (2018) Inventory Management in Supply Chain. Materials Today Proceedings 5,(2-1), 3867-3872. https://doi.org/10.1016/j.matpr.2017.11.641

Tan, B., \& Karabati, S. (2013) Retail inventory management with stock-out based dynamic demand substitution. International Journal of Production Economics, 145(1), 78-87. https://doi.org/10.1016/j.jipe.2012.10.002

Tubino, D.F. (2009). Planejamento e controle de produção: teoria e prática (2nd ed.). São Paulo: Atlas.

Wanke, P. (2011). Gestão de estoques na cadeia de suprimentos: Decisões e modelos qualitativos (3rd ed.). São Paulo: Atlas.

Vago, F.R.M., Sousa, C.V., Melo, J.M. C., Lara, J.E., Fagundes, A.F.A., \& Samapio, D.O. (2013). A importância do gerenciamento de estoque por meio da ferramenta curva ABC. Revista Sociais e Humanas, 26(3), 638-655.

Journal of Industrial Engineering and Management, 2021 (www.jiem.org)

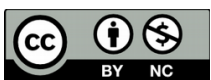

Article's contents are provided on an Attribution-Non Commercial 4.0 Creative commons International License. Readers are allowed to copy, distribute and communicate article's contents, provided the author's and Journal of Industrial Engineering and Management's names are included. It must not be used for commercial purposes. To see the complete license contents, please visit https://creativecommons.org/licenses/by-nc/4.0/. 